\title{
Efficacy of non-pharmacological methods used for treating tobacco dependence: meta-analysis
}

\author{
Skuteczność niefarmakologicznych metod leczenia uzależnienia od tytoniu - metaanaliza
}

\author{
Malgorzata M. Bala, Wiktoria Lesniak \\ Department of Internal Medicine, Jagiellonian University School of Medicine, Krakow, Poland
}

\begin{abstract}
Summary: Objectives. The present paper discusses available data concerning the efficacy of non-pharmacological methods used in smoking cessation and describes the results of newly performed meta-analyses testing the 12-month efficacy of these methods. This study is part of a more comprehensive program analyzing the efficacy and cost-effectiveness of different methods used in smoking cessation. Patients and methods. During the first stage of the study a systematic review of available data was made in order to identify methods used in smoking cessation and assess their efficacy on the basis of already existing reliable systematic reviews or meta-analyses. In the second stage of the study the efficacious and available in Poland methods (identified during the first stage by available data search and interviews with healthcare providers) were tested using new meta-analyses with the aim to define their efficacy in achieving at least the12-month continuous or prolonged abstinence. Results. The findings of the first stage of the study revealed that the reviews performed according to the Cochrane Collaboration methodology contained the most complete and up-to-date data. Meta-analyses of randomised controlled trials performed during the second part of the study showed that non-pharmacological smoking cessation methods available in Poland, namely the physician's simple advice and individual and group counseling, increased the probability of smoking cessation and smoking abstinence for $\geq 12$ months by 1.5 to 2 times and the number of patients who need to be treated to have one patient who stops smoking was about 30 for more intensive methods and 60 for the physician's simple advice. Conclusions. The study confirmed that non-pharmacological smoking cessation methods available in Poland, i.e. the physician's advice and individual and group counseling, increase the probability of smoking abstinence, and determined the 12-month effects of these interventions.
\end{abstract}

Key words: individual counseling, meta-analysis, physician's advice, tobacco dependence, treatment efficacy

\section{INTRODUCTION}

Smoking is a health problem of a considerable social significance on a global scale. It is estimated that there are over one billion adult smokers all over the world. Smoking is a cause of diseases leading to premature death and disability. Smoking, particularly cigarette smoking, is a predominant risk factor for lung cancer, as well as cardiovascular and respiratory system diseases (in particular chronic obstructive pulmonary disease [COPD]) [1-3].

Available data for the years 1990-1994 for the Polish population show that approx. $30 \%$ of deaths in males and approx. $6 \%$ deaths in females were directly caused by smoking, whereas the total annual mortality attributable to smoking in Poland is

Correspondence to:

Malgorzata M. Bala, MD, PhD, Department of Internal Medicine, Jagiellonian University School of Medicine, Str. Skawinska 8, 31-066 Krakow, Poland, phone: +48-12-293-42-36, fax: +48-12-293-40-30, e-mail: gosiabala@mp.pl

Received: November 29, 2007. Accepted in final form: December 11, 2007.

Conflict of interest: none declared.

Pol Arch Med Wewn. 2007; 117 (11-12): 504-510

Copyright by Medycyna Praktyczna, Kraków 2007 estimated for approx. 70,000 (60,000 in males and 10,000 in females). For the aforementioned population, the mean loss of life span due to smoking was 21 years [4]. Currently in Poland, approximately $39 \%$ of adult males and $23 \%$ of adult females smoke cigarettes every day (according to research by Maria Skłodowska-Curie Memorial Cancer Centre and Institute of Oncology), among persons $\geq 40$ years of age the percentage is $34 \%$ and 22\%, respectively [5]. Approximate estimates show that annual expenditures on treatment of smoking related diseases in Poland amount to 18 billion PLN, and if prevalence of smoking does not change, the direct cost of treatment within 20 years will increase to 198 billion PLN [6].

Smoking cessation brings substantial health benefits. A long-term observational study showed that smoking cessation at the age of 25-34 enables gaining 10 years of life in comparison with persons still smoking, and survival curves are similar to the ones of non-smoking males. Smoking cessation at the age of 35-44 is associated with life span extension by 9 years in comparison with persons still smoking, at the age of $45-54$ - by 6 years, and at the age of 55-64 - by 3 years [7]. A systematic review of 20 prospective cohort studies showed 
that smoking cessation, even among persons with already diagnosed ischemic heart disease, is associated with a reduction in death risk due to any cause (relative risk [RR] 0.64, 95\% CI $0.58-0.71$ ), as well as in the risk of repeat of myocardial infarction (RR 0.68, 95\% CI 0.57-0.82) [8].

In the reports concerning the situation of health care in Poland, published in recent years, attention was drawn to insufficient, as compared with most of the industrialized countries, use of reliable information derived from scientific reports and economic analyses in the process of health policy planning and decision making in health care (e.g. in determination of list of reimbursed drugs) [9,10].

Reduction in smoking prevalence in Poland by introducing the interventions of confirmed efficacy into tobacco dependence treatment, may be translated into reduction in morbidity and mortality due to smoking related diseases, thus into reduction in costs of tobacco related diseases treatment.

Identification of methods used for tobacco dependence treatment (smoking cessation) based on systematic review and their efficacy analysis based on reliable scientific research, will make it possible to determine which of them could be of benefit and should be applied on a wider scale.

\section{PATIENTS AND METHODS}

The objective of the study was to assess the efficacy and costeffectiveness of methods applied in tobacco dependence treatment. Current report is dedicated only to analysis of efficacy of non-pharmacological methods used in smoking cessation.

\section{Systematic review of data to identify the tobacco dependence treatment methods}

The following electronic databases were searched (in alphabetical order): Addiction Abstracts, AMED, ASH (Action on Smoking and Health), ASSIA, BIDS-IBSS, CINAHL, Cochrane Library (Database of Cochrane Systematic Reviews and DARE), Conference Paper Index, CSA, Dirline, EIFL Direct, EMBASE, ERIC, Healthstar, Hstat, IBZ, IDEAL, ISI, MEDLINE via PubMed, ProQuest, PsycINFO, Science Direct, Sociological Abstracts, Springer Link, Swetsnet, applying the following keywords:

- health problem: 1) smoking; 2) tobacco; 3) tobacco-use-disorder; 4) smok*; 5) cigaret*

- intervention: 6) treatment; 7) treat*; 8) antismok*; 9) anti-smok*

- outcome measure: 10) reduc*; 11) quit*; 12) stop*; 13) abstin*; 14) abstain*; 15) smoking cessation; 16) tobacco-use-cessation

- type of study: 17) systematic review; 18) meta-analysis; 19) metaanalysis; 20) systematic review using "clinical queries" option.

Search was limited to studies carried out on adults. Last search in the aforementioned databases was carried out in March 2004 and in the Cochrane Library in February 2005.
At that stage, the efficacy of the identified methods in increasing the probability of abstinence was assessed on the basis of the existing reliable systematic reviews and meta-analyses.

\section{Criteria of inclusion of a study in analysis}

Systematic reviews or meta-analyses, where the efficacy was assessed based on randomized trials, were included in the efficacy analysis of non-pharmacological smoking cessation methods.

To be included in further analysis an intervention was required to have its efficacy, i.e. a significant difference in the percentage of persons remaining in continuous abstinence after at least 6 months from the beginning of therapy, shown in a reliable systematic review or meta-analysis.

Availability of individual tobacco dependence treatment methods in Poland was defined based on available data and interviews with health service providers.

\section{Reliability assessment}

The identified reports were initially screened for eligibility. After selection of the studies found, their reliability was appraised in accordance with evidence-based medicine principles (EBM) based on special questionnaire drawn up in accordance with current criteria [11-19]. The critical appraisal form for systematic reviews and meta-analyses was prepared based on Critical Appraisal Skills Programme [11] and User's Guide [12] questionnaires.

The results of all the reviews were summarized, and the most up-to-date reliable systematic reviews were selected for further analysis.

\section{Appraisal of efficacy in achieving 12-month abstinence}

In the second stage of the study, for available in Poland and efficacious tobacco dependence treatment methods identified during the first stage, their impact on achieving at least 12-month continuous abstinence (refraining from smoking from the moment of smoking cessation for the period of 12 months; occasional slips/lapses are possible) or prolonged abstinence (refraining from smoking from smoking cessation for 12 months; during the first two weeks from the target date of smoking cessation, isolated slips/lapses are possible) was defined by means of newly performed meta-analyses. Application of data concerning the 12-month abstinence was associated with the fact that the available epidemiological data used in cost-effectiveness analysis and an economic model (risk of death and risk of disease) cover 12-month periods. Moreover, tobacco abstinence lasting at least one year provides a good chance of total success.

Original studies, where the treatment efficacy was expressed as 12-month, continuous or prolonged tobacco absti- 
ARTYKUŁY ORYGINALNE

\begin{tabular}{|c|c|c|}
\hline Intervention & $\begin{array}{l}\text { Number of systematic reviews/meta-analyses } \\
\text { (years of publication) }\end{array}$ & Cochrane review \\
\hline Physician's advice & $2(1997-2004)\left[24^{\mathrm{a}}, 25\right]$ & March $2004[25]^{\mathrm{b}}$ \\
\hline Nurse's advice & $1(2004)\left[24^{\mathrm{a}}, 26\right]$ & June $2003[26]^{\mathrm{b}}$ \\
\hline Individual counseling & $1(2002)[27]$ & The only review: February 2002 [27] \\
\hline Group therapy & $1(2002)[28]$ & The only review: December 2001 [28] \\
\hline \multirow[t]{2}{*}{ Aversion therapy / silver acetate } & 1 (2004) [29] / 1 (1997) [30] & The only review: May 2004 [29] \\
\hline & & The only review: May 1997 [30] \\
\hline Hypnosis & $1(1998)[31]$ & The only review: June 2001 [31] \\
\hline Acupuncture & 6 (1990-2002) [32-37] & The only review: January 2002 [37] \\
\hline Exercise & 1 (2005) [38] & The only review: August 2004 [38] \\
\hline Bioresonance & None & None \\
\hline \multicolumn{3}{|l|}{ a Last searched May 1995} \\
\hline \multicolumn{3}{|c|}{${ }^{\mathrm{b}}$ The most complete and up-to-date search } \\
\hline
\end{tabular}

nence (irrespective of the year of the study publication and the number of persons subjected to intervention) were extracted from reliable systematic reviews and meta-analyses, which were used for initial efficacy assessment; the studies, where abstinence was assessed only during the week preceding the medical control, were excluded. From individual studies, there were extracted numerical data covering the proportions of patients, who ceased smoking as a result of individual interventions and remained abstinent for at least 12 months. For individual types of interventions, the results of original studies were pooled by means of meta-analysis following Mantel-Haenszel procedure [20-23], using StatsDirect statistical package. The results were presecuted as pooled values of the abstinence proportions both in the experimental and control groups, relative benefit, benefit difference, NNT (number needed-to-treat the number of patients who need to be treated in order to have one patient who stops smoking) and $95 \%$ confidence intervals for those values. Statistical significance of the pooled results was calculated by means of the chi-square test, and homogeneity of results between the studies were examined by means of the $\mathrm{Q}$ test.

\section{RESULTS}

During the first stage, systematic reviews and meta-analyses assessing the efficacy of non-pharmacological tobacco dependence treatment methods listed in Table 1 were found.

The most complete and the most up-to-date data were included in the reviews made in accordance with Cochrane Collaboration methodology.

Among the non-pharmacological treatment methods, whose efficacy was unambiguously confirmed, the following are available in Poland: simple advice of a physician (short intervention lasting $\leq 10$ minutes, involving at most 1 additional follow-up visit), individual counseling (intensive intervention, lasting $>10$ minutes or involving $\geq 2$ additional follow-up visits) and group therapy.

\section{Simple advice}

\section{Available reviews}

Efficacy of simple advice (up to 10 minutes) in encouraging the smokers to give up smoking, in comparison with no advice, normal care or self-help materials was demonstrated in 3 systematic reviews. One of them assessed the efficacy of advice provided by physicians, nurses or other health care providers within the scope of primary health care (odds ratio [OR] 1.32, 95\% CI 1.18-1.48 [24]), one review assessed the efficacy of advice provided exclusively by physicians (OR 1.74, 95\% CI $1.48-2.05$ [25]) and another one assessed the advice provided exclusively by nurses (OR 1.76, 95\% CI 1.23-2.53 [26]).

Efficacy appraisal in achieving the 12-month abstinence

According to the information from the health service providers it was determined that in Poland simple advice is provided by physicians. Of 17 studies included in the most up-to-date and reliable Cochrane systematic review [25], 8 studies assessing efficacy of simple advice provided by a physician in achieving 12-month abstinence were included in efficacy analysis (see webappendix). All the included studies were randomized controlled trials, where the patients of the control group did not receive any advice, only self-help leaflets and normal care or did not receive any treatment. 


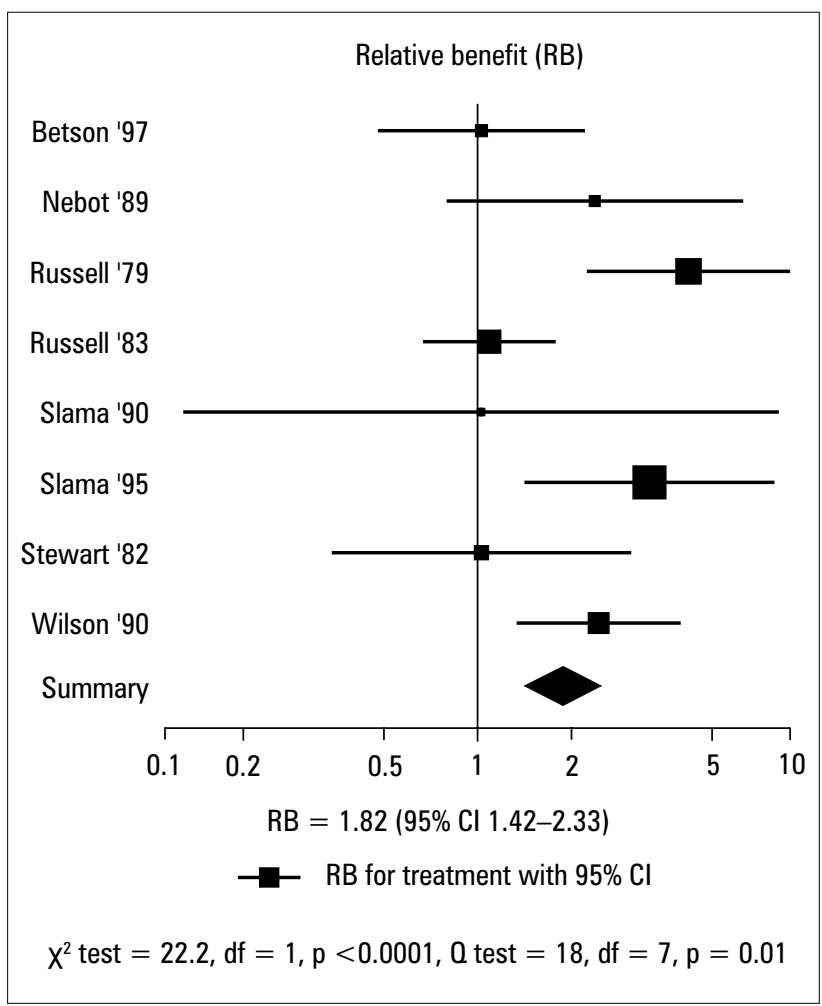

Fig. 1. Efficacy of simple physician's advice in achieving 12-month abstinence - relative benefit vs. no advice. References - see webappendix. Abbreviations: $\mathrm{df}$ - degree of freedom

The results of original studies included in the efficacy analysis were pooled by means of meta-analysis and substantial benefits of provision of the simple physician advice in comparison with no advice were observed (Tab. 2, Fig. 1).

\section{Individual counseling}

\section{Available reviews}

In 3 systematic reviews, the efficacy of different types of individual counseling provided by a physician (OR 2.04, 95\% CI 1.71-2.43 [25]), a nurse (OR 1.43, 95\% CI 1.24-1.64 [26]) or other health care providers (OR 1.62, 95\% CI 1.35-1.94 [27]) was assessed in comparison with the control group, which was not provided with this kind of therapy.

Efficacy appraisal in achieving the 12-month abstinence

Of the aforementioned systematic reviews, further analysis covered randomized controlled trials, where the outcome measure was the 12-month abstinence: 8 studies concerning counseling provided by a physician, 2 concerning counseling provided by a nurse and 5 concerning counseling provided by different health care providers (see webappendix). In each study the patients in the control group were provided with simple advice.
The results of original studies included in the efficacy analysis were pooled by means of meta-analysis and substantial benefits were observed (Tab. 2, Fig. 2).

\section{Group therapy}

\section{Available reviews}

Efficacy of different types of group psychotherapy in comparison with the control group receiving self-help materials or advice (OR 1.97, 95\% CI 1.57-2.48) and in comparison with the control group not provided with any treatment (OR 2.19, 95\% CI 1.42-3.37) was demonstrated in one systematic review [28].

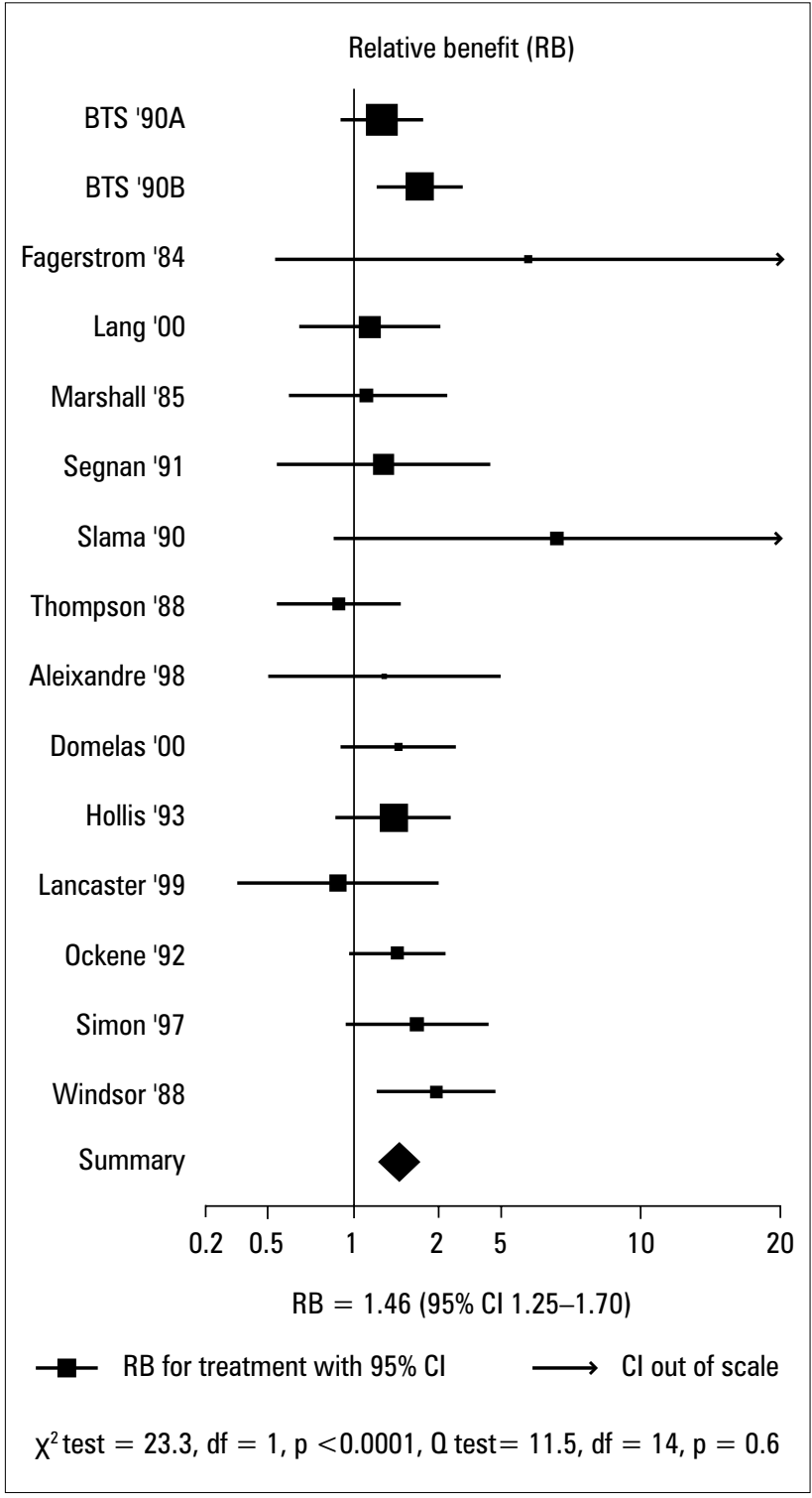

Fig. 2. Efficacy of individual counseling in achieving 12-month abstinence - relative benefit vs. simple advice. References - see webappendix. Abbreviations - see Fig. 1 


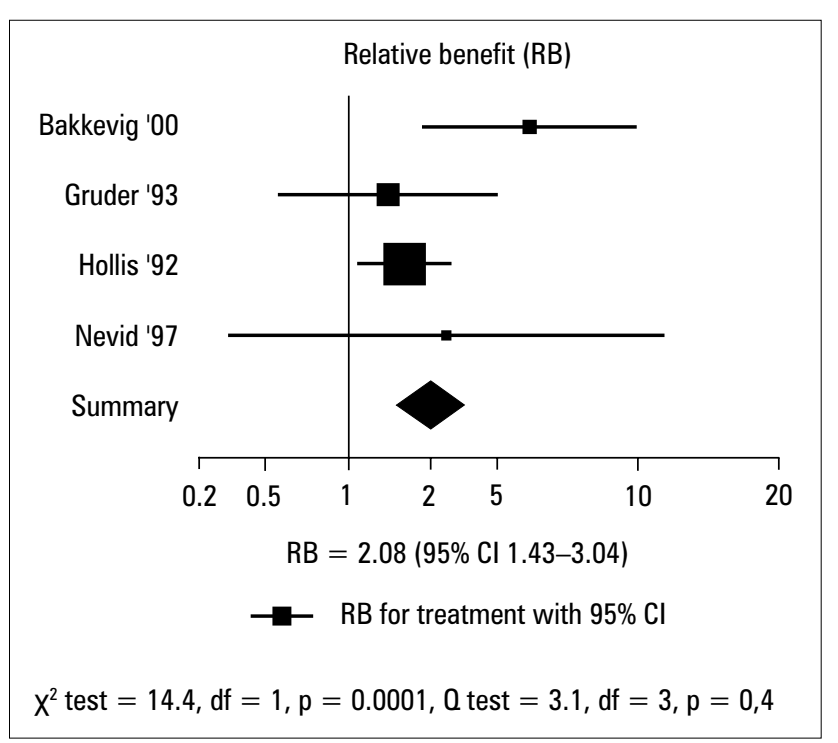

Fig. 3. Efficacy of group therapy in achieving 12-month abstinence - relative benefit vs. simple advice. References - see webappendix. Abbreviations - see Fig. 1

\section{Efficacy appraisal in achieving the 12-month} abstinence

From the number of 24 studies included in systematic review, 4 were included in the efficacy analysis, where the efficacy of group therapy in the 12-month abstinence was evaluated (see webappendix). All the included studies were randomized controlled trials, where the patients of the control group were provided with simple advice and in some studies also with self-help leaflets.

The results of original studies included in the efficacy analysis were pooled by means of meta-analysis and substantial benefits of group therapy in comparison with simple advice were observed (Tab. 2, Fig. 3).

\section{Other non-pharmacological methods of treatment}

\section{Available reviews}

The systematic reviews or meta-analyses found did not unambiguously showed the efficacy of the following non-pharmacological methods:

- aversion therapy and silver acetate (aversion therapy consists of simultaneous application of positive [smoking] and negative reinforcement [e.g. quick smoking of a large number cigarettes and simultaneous concentration on unpleasant impressions or application of silver acetate, which produces unpleasant taste] to create a new conditioned response and thus modified behavior) [29,30]

- hypnosis [31]

- acupuncture [32-37]

- exercise [38].
Systematic reviews, meta-analyses or randomized controlled trials concerning the effectiveness of so-called bioresonance in tobacco dependence therapy were not found $[39,40]$.

\section{DISCUSSION}

The analysis of systematic reviews and meta-analysis of randomized controlled trials assessing the non-pharmacological tobacco dependence treatment methods demonstrated efficacy of the methods available in Poland, viz. the physician's simple advice, individual counseling and group therapy, in increasing the probability of the 12-month tobacco abstinence. For all the aforementioned methods, the probability of smoking cessation in comparison with the control group increased approx. by 1.5 to 2 times. However, the number of patients who need to be treated in order to have one patient who stops smoking (NNT) for the physician's simple advice in comparison with no-advice was 60 , and for individual counseling and group therapy in comparison with simple advice it was 36 and 31, respectively. The results of the study are consisted with the results of other studies and with guidelines for tobacco dependence treatment [41-44].

There is, therefore, the possibility of effective influence on smoking cessation showed by scientific research. However, according to information provided by individual departments of the National Health Fund (Narodowy Fundusz Zdrowia NFZ) or via their websites in 2004, nicotine dependence clinic services (code 1742) were contracted only in 5 NFZ departments. Moreover, smoking advice is one of the components of the cardiovascular disease prophylaxis program and the COPD prophylaxis program currently being contracted in most of NFZ departments.

Apart from non-pharmacological interventions, there are also effective pharmacological methods of tobacco dependence treatment, like nicotine replacement therapy, bupropion or varenicline, recently released on the market. Their addition to non-pharmacological methods results in higher probability of smoking cessation than when applying non-pharmacological methods alone, and NNT ranges from 6 to 21. However, their application cost for the patient is higher, especially as those drugs are not reimbursed (in the year 2004, cost of simple advice was estimated at ca. 7 PLN/day, and that of pharmacological treatment at ca. 10 PLN/day) [45].

Smoking cessation is associated with the reduction in risk of death and morbidity due to tobacco related diseases, therefore, it seems justifiable to introduce a systematic approach to treatment of this dependence using the methods of confirmed effectiveness and, at the same time, to provide information concerning the effectiveness or ineffectiveness of various methods both to physicians and, first of all, to patients.

"Konsensus dotyczący diagnostyki i leczenia zespołu uzależnienia od tytoniu" drawn up by multidisciplinary team of specialists and published in 2006 [44] states that treatment of tobacco dependence is a physician's obligation and he should 


\begin{tabular}{|c|c|c|c|c|c|}
\hline Method & $\begin{array}{l}\text { Treatment \% } \\
(95 \% \mathrm{CI})\end{array}$ & $\begin{array}{l}\text { Control \% } \\
(95 \% \text { CI) }\end{array}$ & $\begin{array}{l}\text { Relative benefit } \\
(95 \% \mathrm{CI})\end{array}$ & $\begin{array}{l}\text { Benefit difference } \\
\text { (95\% CI) }\end{array}$ & $\begin{array}{l}\text { NNT } \\
(95 \% \text { CI) }\end{array}$ \\
\hline $\begin{array}{l}\text { Simple physician's advice } \\
\text { vs. no advice }\end{array}$ & $3.7(3.2-4.2)$ & $2.05(1.62-2.48)$ & $1.82(1.42-2.33)$ & $0.017(0.01-0.023)$ & $60(43-99)$ \\
\hline $\begin{array}{l}\text { Individual counseling } \\
\text { vs. simple advice }\end{array}$ & $9.1(8.3-9.9)$ & $6.2(5.5-7.0)$ & $1.46(1.25-1.70)$ & $0.029(0.017-0.04)$ & $36(26-59)$ \\
\hline $\begin{array}{l}\text { Group therapy } \\
\text { vs. simple advice }\end{array}$ & $6.3(4.9-7.7)$ & $3.0(2.2-3.9)$ & $2.08(1.4-3.0)$ & $0.03(0.02-0.05)$ & $31(21-62)$ \\
\hline \multicolumn{6}{|c|}{ NNT - the number of patients who need to be treated in order to have one patient who stops smoking (number needed-to-treat) } \\
\hline
\end{tabular}

ask his patients about smoking, just the same as he asks about disease symptoms while taking their medical history, and should encourage them to give up the habit, presenting different available possibilities of non-pharmacological and pharmacological support. It is also recommended to introduce tobacco dependence treatment to the programs financed by the NFZ. Although the act of 9 November 1995 on protection of health against the consequences of using tobacco and tobacco products, as amended [46], maintains that treatment of tobacco dependence provided in public health centers is free, the number of contracted nicotine dependence clinic is not buoyant. Cardiovascular disease prophylaxis programs financed by the NFZ include health education and encouragement to change lifestyle, the COPD prophylaxis program describes also smoking advice.

It is extremely important to make physicians and other health care providers aware of the fact that even a simple few minutes' advice may increase a smoker's motivation to give up the habit. Health campaigns in Poland had impact on both the smokers' and the health care providers' awareness of significance of this health problem. This, however, may not yet adequately translate into practice, due to the fact that physicians still do not ask all their patients about smoking habit and do not advice them to give up smoking [47]. Starting of training in tobacco dependence treatment already during medical studies seems to be helpful.

Presentation of the tobacco dependence problem in the specialist training programs is also insufficient. In current programs for general practitioners, the contents of public health course mention nicotinism [48]. In the pulmonology training programs, within the scope of the required competence, knowledge of smoking eradication rules was mentioned [49]. This training was not clearly included in the internal medicine and cardiology programs $[50,51]$. It was only mentioned in the latter program that the aim of the current course on health promotion is to familiarize a physician becoming a specialist with contemporary rules of prevention of coronary heart disease and arterial hypertension risk factors, as well as promotion of healthy lifestyle, and the scope of training should include epidemiology, diagnostics and therapy in persons with atherosclerosis, coronary heart disease and arterial hypertension risk factors [51].
The second aspect raised in the presented study is assessment of possibility of broader use of reliable information from scientific reports in the process of health policy planning and in health care decision making, both at the level of central authorities, and at the lowest level, i.e. in a surgery. In most of the tobacco dependence treatment methods, the most up-to-date and reliable, and usually the only source of information, was the systematic review published in the Cochrane Library, which is currently available free of charge for everyone in Poland (Medical Technology Assessment Agency, website: www.aotm.gov.pl). The Medical Technology Assessment Agency was established by the directive of the Minister of Health of 30 June 2006 [52]. Its establishment boosts hope for still broader use of scientific evidence in health care decision making in Poland (according to EBM principles). Drawing up, verification, collection, making available and dissemination of information about assessment of medical technology made in the Republic of Poland and other countries and production of recommendations concerning medical technology for the minister in charge of health are among its objectives.

\section{ACKNOWLEDGEMENTS}

Scientific research financed by the State Committee for Scientific Research in the years 2004-2005 as a research project No 2 P05D 07126.

We would like to thank Lukasz Strzeszyński for his assistance in preparation of the manuscript.

\section{REFERENCES}

1. Zatoński W, Przewoźniak K, eds. Bank Światowy. Przeciwko epidemii. Działania rządów a ekonomika ograniczenia konsumpcji tytoniu. Kraków, Medycyna Praktyczna, 2002

2. Wyser C, Bolliger CT. Smoking-related disorders. In: Bolliger CT, Fagerström KO, eds. The tobacco epidemic. Prog Respir Res. Basel, Karger. 1997; 28: 78-106.

3. National Center for Health Statistics. Mortality from diseases associated with smoking. National Vital Statistics System. Series 20. No. 17. DHEW Publication No. (PHS) 82-1854. Washington, DC, US Government Printing Office, 1982.

4. Zatoński W, Przewoźniak K, eds. Palenie tytoniu w Polsce: postawy, następstwa zdrowotne i profilaktyka. Warszawa, Centrum Onkologii - Instytut im. Marii Skłodowskiej-Curie, 1999. 
5. Niżankowska-Mogilnicka E, Mejza F, Buist AS, et al. Prevalence of COPD and tobacco smoking in Malopolska region - results from the BOLD Study in Poland. Pol Arch Med Wewn. 2007; 117: 402-409.

6. Epidemiological and Health-Economic Model for Smoking-Related Morbidity Manual and Users' Guide. World Health Organization. May, 2000.

7. Doll R, Peto R, Boreham J, et al. Mortality in relation to smoking: 50 years' observations on male British doctors. BMJ. 2004; 328: 1519-1533.

8. Critchley JA, Capewell S. Mortality reduction associated with smoking cessation in patients with coronary heart disease. A systematic review. JAMA. 2003; 290 86-97.

9. Ministerstwo Zdrowia, Zespół ds. Rozwiązań Systemowych w Ochronie Zdrowia Strategia zmian w systemie opieki zdrowotnej: szansa przezwyciężenia kryzysu. Raport przygotowany pod kierunkiem C.W. Włodarczyka. Warszawa, 15 marca 2004

10. Banta HD. Standardy świadczeń zdrowotnych nabywanych w ramach systemu opieki zdrowotnej w Polsce. Projekt finansowany ze środków kredytu Banku Światowego nr pożyczki 3466-POL na zlecenie Ministerstwa Zdrowia, Biura ds. Zagranicznych Programów Pomocy w Ochronie Zdrowia. TNO Prevention and Health, 2002.

11. Critical Appraisal Skills Programme and Health Care Libraries Unit. Evidence-based Health Care. An open learning resource for health care practitioners. CASP and HCLU, United Kingdom, 1999.

12. Oxman $A D$, Cook DJ, Guyatt GH. Users' guides to the medical literature. VI. How to use an overview. Evidence-Based Medicine Working Group. JAMA. 1994; 272: 1367-1371

13. Hayward RSA, Wilson MC, Tunis SR, et al. Users' guides to the medical literature VIII. How to use clinical practice guidelines. A. Are the recommendations valid? JAMA. 1995; 274: 570-574.

14. Wilson MC, Hayward RSA, Tunis SR, et al. Users' guides to the medical literature VIII. How to use clinical practice guidelines $B$. What are the recommendations and will they help you in caring for your patients? JAMA. 1995; 274: 1630-1632.

15. Jadad AR, Moore RA, Carroll D, et al. Assessing the quality of reports of randomized clinical trials: Is blinding necessary? Control Clin Trials. 1996; 17: 1-12.

16. Jaeschke R, Cook D, Guyatt G. Evidence based medicine (EBM), czyli praktyka medyczna oparta na wiarygodnych i aktualnych publikacjach (POWAP). Med Prakt. 1999; wyd specjal 1: 3-76.

17. Spławiński J. Receptariusz szpitalny. Jaworzno, Unimed, 1998.

18. Guyatt GH, Sackett DL, Cook DJ. Users' guides to the medical literature. II. How to use an article about therapy or prevention. A. Are the results of the study valid? JAMA. 1993; 270: 2598-2601.

19. Guyatt GH, Sackett DL, Cook DJ. Users' guides to the medical literature. II. How to use an article about therapy or prevention. B. What were the results and will they help me in caring for my patients? JAMA. 1994; 271: 59-63.

20. Egger M, Smith GD, Altman DG, eds. Systematic reviews in health care: metaanalysis in context. London, BMJ Publishing Group, 2001

21. Alderson P, Green S, Higgins JPT, eds. Cochrane Reviewers' Handbook 4.2.2 [updated March 2004]. The Cochrane Library, Issue 1. Chichester, John Wiley \& Sons, Ltd, 2004

22. Whitehead A, Whitehead J. A general parametric approach to the meta-analysis of randomized clinical trials. Statistics in Medicine. 1991; 10: 1665-1677.

23. Greenland S, Robins J. Estimation of a common effect parameter from sparse follow-up data. Biometrics. 1985; 41: 55-68.

24. Ashenden R, Silagy $C$, Weller D. A systematic review of the effectiveness of promoting lifestyle change in general practice. Family Practice. 1997; 14: 160-175.

25. Lancaster T, Stead LF. Physician advice for smoking cessation. The Cochrane Database Syst Rev. 2004; 4: CD000165.

26. Rice VH, Stead LF. Nursing interventions for smoking cessation. The Cochrane Database Syst Rev. 2004; 1: CD001188.

27. Lancaster T, Stead LF. Individual behavioural counselling for smoking cessation The Cochrane Database Syst Rev. 2002; 3: CD001292.

28. Stead LF, Lancaster T. Group behaviour therapy programmes for smoking cessation. The Cochrane Database Syst Rev. 2002; 2: CD001007.

29. Hajek P, Stead LF. Aversive smoking for smoking cessation. The Cochrane Database Syst Rev. 2004; 3: CD000546.

30. Lancaster T, Stead LF. Silver acetate for smoking cessation. The Cochrane Database Syst Rev. 1997; 3: CD000191.

31. Abbot NC, Stead LF, White AR, et al. Hypnotherapy for smoking cessation. The Cochrane Database Syst Rev. 1998; 2: CD001008.

32. Ashenden R, Silagy C A, Lodge M, i wsp. A meta-analysis of the effectiveness of acupuncture in smoking cessation. Drug and Alcohol Review. 1997; 16: 33-40

33. Law M, Tang JL. An analysis of the effectiveness of interventions intended to help people stop smoking. Arch Intern Med. 1995; 155: 1933-1941.

34. Linde K, Vickers A, Hondras M, et al. Systematic reviews of complementary therapies - an annotated bibliography. Part 1: acupuncture. BMC Complementary and Alternative Medicine. 2001; $1: 3$.

35. Moner SE. Acupuncture and addiction treatment. J Addict Dis. 1996; 15: 79 100.

36. Ter Riet G, Kleijnen J, Knipschild P. A meta-analysis of studies into the effect of acupuncture on addiction. Br J Gen Pract. 1990; 40: 379-382.
37. White AR, Rampes $\mathrm{H}$, Ernst E. Acupuncture for smoking cessation. The Cochrane Database Syst Rev. 2002; 2: CD000009.

38. Ussher $\mathrm{MH}$, West $\mathrm{R}$, Taylor $\mathrm{AH}$, et al. Exercise interventions for smoking cessation. The Cochrane Database Syst Rev. 2005; 1: CD002295.

39. Ernst E. Bioresonance, a study of pseudo-scientific language. Forsch Komplementarmed Klass Naturheilkd. 2004; 11: 171-173.

40. Zarząd Główny Polskiego Towarzystwa Alergologicznego. Terapia biorezonansem MORA i BIOCOM (biokomunikacja). Pol Merk Lek. 1997; 3: 40-44.

41. National Institute for Health and Clinical Excellence. Brief interventions and referral for smoking cessation in primary care and other settings. Public Health Intervention Guidance No.1. NICE, London, marzec 2006.

42. Fiore MC, Bailey WC, Cohen SJ. Treating tobacco use and dependence. Clinical practice guideline. Rockville, MD, U.S. Department of Health and Human Services, Public Health Service, June 2000 (http://www.surgeongeneral.gov/tobacco/treating tobacco_use.pdf).

43. Tønnesen P, Carrozzi L, Fagerström KO, et al. Smoking cessation in patients with respiratory diseases: a high priority, integral component of therapy. Eur Respir J. 2007; 29: 390-417.

44. Konsensus dotyczący rozpoznawania i leczenia zespołu uzależnienia od tytoniu. Med Prakt. 2006; wyd specjal 7: 5-24.

45. Bała $M$, Leśniak W. Efficacy of pharmacological methods used for treating tobacco dependence - metaanalysis. Pol Arch Med Wewn. (submitted for publication).

46. Ustawa z dnia 9 listopada 1995 r. o ochronie zdrowia przed następstwam używania tytoniu i wyrobów tytoniowych. Dziennik Ustaw z dnia 30 stycznia 1996 r. Nr 10 poz. 55 z późn. zm.

47. Targowski T, Rożyńska R, From S. Stosowanie zasad minimalnej interwencji przez lekarzy podstawowej opieki zdrowotnej w ocenie pacjentów uzależnionych od nikotyny. Przegl Lek. 2004; 61: 1177-1179.

48. Program specjalizacji w medycynie rodzinnej. Program podstawowy dla lekarzy po stażu podyplomowym. Warszawa, CMKP, 2005.

49. Program specjalizacji w chorobach płuc. Program dla lekarzy posiadajacych specjalizacje II stopnia lub tytuł specjalisty w chorobach wewnetrznych lub pediatrii. Warszawa, CMKP, 2002.

50. Program specjalizacji w chorobach wewnętrznych. Program podstawowy dla lekarzy po stażu podyplomowym. Warszawa, CMKP, 2005.

51. Program specjalizacji w kardiologii. Program podstawowy dla lekarzy po stażu podyplomowym. Warszawa, CMKP, 2007.

52. Zarządzenie Ministra Zdrowia z dnia 30 czerwca 2006 r. w sprawie Agencji Oceny Technologii Medycznych.

\section{WEBAPPENDIX}

Primary studies included in the analysis (main references).

Simple physician's advice

1. Betson $\mathrm{CL}$, Lam $\mathrm{TH}$, Chung $\mathrm{WH}$, et al. A randomized controlled trial on smoking cessation in government out-patient clinics in Hong Kong (Abstract). Proceedings of the 10th World Conference on Tobacco or Health; 1997 Aug 24-28. Beijing, China, 1997: 113

2. Nebot-Adell M, Soler-Vila M, Martin-Cantera C, et al. Effectiveness of the physician's advice to quit smoking: evaluation of the impact a year after the fact. Rev Clin Esp. 1989; 184: 210-215.

3. Russell MA, Wilson C, Taylor C, Baker CD. Effect of general practitioners' advice against smoking. Br Med J. 1979; 2: 231-235.

4. Russell MA, Merriman R, Stapleton J, Taylor W. Effect of nicotine chewing gum as an adjunct to general practitioner's advice against smoking. Br Med J 1983; 287 $1782-1785$.

5. Slama K, Redman S, Perkins J, et al. The effectiveness of two smoking cessation programmes for use in general practice: a randomised clinical trial. Br Med J. 1990; 300: 1707-1709.

6. Slama K, Karsenty $\mathrm{S}$, Hirsch A. Effectiveness of minimal intervention by general practitioners with their smoking patients: a randomised controlled trial in France. Tob Control. 1995; 4: 162-169.

7. Stewart PJ, Rosser WW. The impact of routine advice on smoking cessation from family physicians. Can Med Assoc J. 1982; 126: 1051-1054.

8. Wilson DH, Wakefield MA, Steven ID, et al. "Sick of Smoking": evaluation of a targeted minimal smoking cessation intervention in general practice. Med $\mathrm{J}$ Aust. 1990; 152: 518-521.

\section{Individual counselling}

1. Aleixandre i Martí E, Casanova Matutano MA, Mitjans Lafont $\mathrm{J}$, et al. Clinical trial of 2 tobacco use cessation interventions in primary care. Aten Primaria. 1998; 22: 424-428. 
2. Dornelas EA, Sampson RA, Gray JF, et al. A randomized controlled trial of smoking cessation counseling after myocardial infarction. Prev Med. 2000; 30: 261-268.

3. Ockene JK, Kristeller J, Goldberg R, et al. Smoking cessation and severity of disease: The coronary artery smoking intervention study. Health Psychol. 1992; 11 119-126.

4. Simon JA, Solkowitz SN, Carmody TP, et al. Smoking cessation after surgery a randomized trial. Arch Intern Med 1997; 157: 1371-1376.

5. Windsor RA, Lowe JB, Bartlett EE. The effectiveness of a worksite self-help smoking cessation program: a randomized trial. J Behav Med. 1988; 11: 407-421.

\section{Individual counselling provided by physician}

1. Research Committee of the British Thoracic Society. Smoking cessation in patients: two further studies by the British Thoracic Society. Thorax. 1990; 45: 835-840.

2. Fagerström KO. Effects of nicotine chewing gum and follow-up appointments in physician-based smoking cessation. Prev Med. 1984; 13: 517-527.

3. Lang T, Nicaud V, Slama K, et al. Smoking cessation at the workplace. Results of a randomised controlled intervention study. J Epidemiol Community Health. 2000; 54: 349-354.

4. Marshall $A$, Raw M. Nicotine chewing gum in general practice: effect of follow up appointments. Br Med J. 1985; 290: 1397-1398.

5. Segnan N, Ponti A., Battista RN, et al. A randomized trial of smoking cessation in terventions in general practice in Italy. Cancer Causes Control. 1991; 2: 239-246.

6. Slama K, Redman S, Perkins J, et al. The effectiveness of two smoking cessation programmes for use in general practice: a randomised clinical trial. Br Med J. 1990; 300: 1707-1709.

7. Thompson RS, Michnich ME, Friedlander L, et al. Effectiveness of smoking cessation interventions integrated into primary care practice. Med Care. 1988; 26: 62 76.

\section{Individual counselling provided by nurse}

1. Hollis JF, Lichtenstein E, Vogt TM, et al. Nurse-assisted counseling for smokers in primary care. Ann Intern Med. 1993; 118: 521-525.

2. Lancaster T, Dobbie W, Vos K, et al. Randomised trial of nurse-assisted strategies for smoking cessation in primary care. Br J Gen Pract. 1999; 49: 191-194.

\section{Group therapy}

1. Bakkevig 0, Steine S, von Hafenbradl K, et al. Smoking cessation - a comparative randomised study between management in general practice and the behavioura programme SmokEnders. Scand J Prim Health Care. 2000; 18: 247-251.

2. Gruder CL, Mermelstein RJ, Kirkendol S, et al. Effects of social support and relapse prevention training as adjuncts to a televised smoking-cessation intervention. J Consult Clin Psychol 1993; 61: 113-120.

3. Hollis JF, Lichtenstein E, Vogt TM, et al. Nurse-assisted counseling for smokers in primary care. Ann Intern Med. 1993; 118: 521-525.

4. Nevid JS, Javier RA. Preliminary investigation of a culturally-specific smoking cessation intervention for Hispanic smokers. Am J Health Promot. 1997; 11: 198-207. 